\title{
岩石はりの曲げにおける中立軸の移動
}

$$
\text { 正会員堀部富 男** }
$$

\section{Shift of Neutral Axis of Slab of Rock at Bending Test}

Tomio HORIBE

It is said that the bending strength of a rock is measured greater than the tensile strength. As one of this reason, the shift of the neutral axis of the slab of a rock toward the side of the compression is considered. The author obsereved the strain of each fiber of the slabby specimen by the electric strain gauge. And as a result, the amount of the shift of the neutral axis was $6 \sim 11 \%$ of the height of the specimen.

\section{1. 緒}

\section{言}

岩石はりの曲げ試験を行つて曲げ強さ算出すると, これを単軸引張試験あるいは圧裂試験によつて算出した 引張強さに比へて大になつてあらわれる。筆者が常磐宸 破産の砂岩, 頁岩について行つた結果もその通りで,こ れを例示すると第1表の様になる。このように曲げ強さ が引張強さに比べた大に算出されるのは，曲げ試験にお けるはりの引張側の外皮瀻維にお敌る引張強さが，引張 試験における引張強さよりも大であることを意味するの ではなく，理由は別にある。この理由に関連してはりの

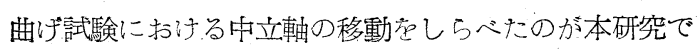
ある。

第 1 表

\begin{tabular}{|c|c|c|c|}
\hline 種 & 引張强 さ $\mathrm{kg} / \mathrm{cm}^{2}$ & $2 \mid$ 曲け强さ $\mathrm{kg} / \mathrm{cm}^{2}$ & 備 \\
\hline 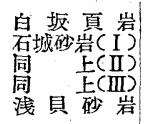 & $\begin{array}{r}15.2 \\
7.0 \\
12.0 \\
9.1 \\
10.3\end{array}$ & $\begin{array}{l}28.3 \\
37.7 \\
41.8 \\
21.0 \\
29.8\end{array}$ & 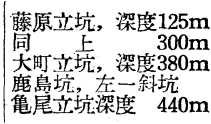 \\
\hline
\end{tabular}

\section{2. 中立軸移動の理論}

はりの曲げを取扱う場合には次の仮定䛌設て考察さ れている。

（1）はりは真直ぐで，横断面が一様であり，かつ材 料は等質等方である。

（2）はりの縦䋐維に直交していた横断平面は曲げら れたあとも平面を保ち，かつ縱繊維に直交する。

(3) 䌅瀻維は相互間に力を及活し合わない。

（4）繊維応力と繊維とズミとの関係泣，この材料で 作つた試験片に単軸引張, 単軸圧縮荷重を作用させたと きに得られる応力ととズミとの関係に等しい。

* 昭和 30 年 4 月 28 日受理

** 東北大学助敉授 鉱山学敉室
（5）はりは曲げモーメントのみを受ける。

さて, はりを曲げると, 中立軸を境として,引張側には $\int_{0}^{e_{1}} \sigma_{z} \cdot d f$, 圧縮側には $\int_{0}^{e_{2}} \sigma_{d} \cdot d f$ なるが生じ, これが平 衡にあれば,

$$
\begin{gathered}
\int_{0}^{e_{1}} \sigma_{z} \cdot d f-\int_{0}^{e_{2}} \sigma_{d} \cdot d f=0 \cdots \cdots \cdots . . . \\
\text { またその時の曲げモーメントは } \\
M_{b}=\int_{0}^{e_{1}} \sigma_{z} \cdot \eta \cdot d f+\int_{0}^{e_{2}} \sigma_{d} \cdot \eta \cdot d f
\end{gathered}
$$

ただし， $\sigma_{z}$ : 引張灾力, $\sigma_{a} d$ : 圧縮応力, $d f$ : 繊維面積, $\eta$ : 中立軸から繊維までの距離, $e_{1}\left(e_{2}\right):$ 中立軸から引張 側 (圧縮側) 外皮繊維までの距離, $M_{b}$ : 曲げモーメント であらわされることは一般の教科書にある。

しかして、はりの材料が, これ策軸引張ならびに圧 縮試験危行つた場合にその応力 $(\sigma)$ とヒズミ $(\varepsilon)$ との関 係がいずれも

$$
\varepsilon=\alpha \cdot \sigma
$$

なる関係学示し，かつ弾性倸数 $\alpha$ がいすれれの場合も等し いとすれぱ，纎維态力とクとの関保が

$$
\begin{aligned}
& \sigma_{1}=\frac{M_{b}}{I} \eta \quad \text { (引張側)， } \sigma_{2}=\frac{M_{b}}{I} \eta \text { (告縮側) } \\
& \text { ただし } I \text { : 断面二次もーメント }
\end{aligned}
$$

になり,応力とクとの関係が常に直線関係に西り, 中立 軸は移動しない。

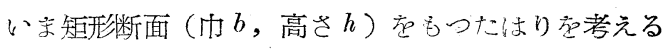
之, 外皮繊維までの距離は, 引張側は $\eta=+e_{1}$, 王縮側は

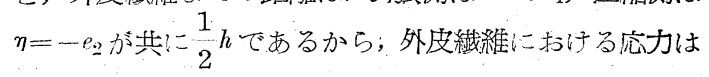

$$
\sigma=\frac{M_{b}}{I} \cdot 2 h=\frac{M_{b}}{1 / 6 b h^{2}}
$$

であらかされ，この応力がその強さに達した時に破壤が おこるとして，曲げ強さが計算されるのである。

しかるに岩石のように応力ととズミ之の関係が、フッ クの法則に従わないで，

$$
\varepsilon=\alpha \cdot \sigma^{m}
$$


なる形をとり,かつ単軸引張ならびに圧縮試験におらて, 引張では $\alpha_{1} m_{1}$, 圧縮では $\alpha_{2} m_{2}$ を示すような材料のは

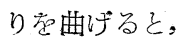

引唇側では $\varepsilon=\alpha_{1} \sigma_{z} m_{1}=\frac{\eta}{\rho}$ (ただし $\rho:$ 曲率半径)

圧縮側では $\varepsilon=\alpha_{2} \sigma a m_{2}=\frac{\eta}{\rho}$

になる。故に

$$
\sigma_{z}=\left(\frac{\eta}{\alpha_{1} \rho}\right)^{\frac{1}{m_{1}}}, \sigma_{d}=\left(\frac{\eta}{\alpha_{2} \rho}\right)^{\frac{1}{m_{2}}}
$$

中立軸から最も外側の外皮繊維におおける応力は。それぞ 机

$$
\begin{gathered}
\sigma_{1}=\left(\frac{e_{1}}{\alpha_{1} \rho}\right)^{\frac{1}{m_{1}}}, \sigma_{2}=\left(\frac{e_{2}}{\alpha_{2} \rho}\right)^{\frac{1}{m_{2}}} \\
\therefore \quad \frac{\sigma_{2}^{m_{2}}}{\sigma_{1} m_{1}}=\frac{\alpha_{1}}{\alpha_{2}} \frac{e_{2}}{e_{1}} \quad \text { ¿らに } \sigma_{2}=\left(\frac{\alpha_{1}}{\alpha_{2}} \frac{e_{2}}{e_{1}}\right)^{\frac{1}{m_{2}}} \quad \frac{m_{1}}{\sigma_{m_{2}}}
\end{gathered}
$$

こ礼赏 (1) 式に代入して整理すると

$$
\frac{e_{1}}{e_{2}}=\left\{\frac{\alpha_{1}}{\alpha_{2}}\left[\frac{m_{2}\left(m_{1}+1\right)}{m_{1}\left(m_{2}+1\right)}\right]^{m_{2}} \sigma_{1} m_{1}-m_{2}\right\} \frac{1}{m_{2}+1}
$$

な打矩形断面の場合の曲げモーメントは

$$
\boldsymbol{M}_{b}=\sigma_{1} b\left\{\frac{m_{1}}{2 m_{1}+1} e_{1}^{2}+\left(\frac{\alpha_{1}}{\alpha_{2}} \frac{e_{2}}{e_{1}}\right)^{\frac{1}{m_{2}}} \frac{m_{2}}{2 m_{2}+1} \sigma_{1} \frac{m_{1}-m_{2}}{m_{2}} e_{2}{ }_{2}\right\}
$$

そ礼 $(3)$ 式から, 単軸引張ならびに圧縮試験によ つて各々の応力ととズミとの関係它求め, その倸数とし ての $\alpha_{1} m_{1}, \alpha_{2} m_{2}$ 艺見出だせば，任意の $\sigma_{1}$ の時の $e_{1} / e_{2}$ （ただし $e_{1}+e_{2}=h$ ) 知ることが出来る。かつ $e_{1} / e_{2}$ は $\sigma_{1}$ によって值が変わるから, 曲げ試験粱行うと応力の増加 と共に $e_{1} / e_{2}$ の值が変わり，したがつて中立軸は移動する のである。しかして岩石や鋳鉄の場合は中立軸が圧縮側 に移動し， $e_{1} / e_{2}>1$ なる様子在示し，松材の場合は中立 軸が引張側に移動するといわれている。

\section{3. 中立軸移動の測定}

岩石はりが上記のように曲げによつて中立軸が移動を おこすならば，岩石はりの側面にあらかじめその縱瀻維 に沿つてとズミ計を平行に多数貼つて抢き，これに荷重

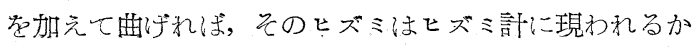
ら，ヒズミが零なる点党荷重增加亡共にたどつて行けば 中性線の移動がわかることになる。

\section{a) 試料}

使用した岩石注常磐産の白坂頁岩および浅貝砂岩で, これを $30 \mathrm{~cm} \times 4 \mathrm{~cm} \times 2.5 \mathrm{~cm}$ (長さ, 高さ, 巾) の短冊形 に整形し，成層面の方向は長さおよび高さの辺に平行に そつた。

\section{b） ストレンゲージ製作，貼付}

曲げによる各䄳維のせズミを測るので市販のゔージで は思わしくない。それてで筆者は旭電線製のアドバンス線

1) 実際に径を測定したこころ $0.021 \mathrm{~mm} \phi$ であつた。

2). 筆者：日本鉱業全誌，昭26.11, 537頁

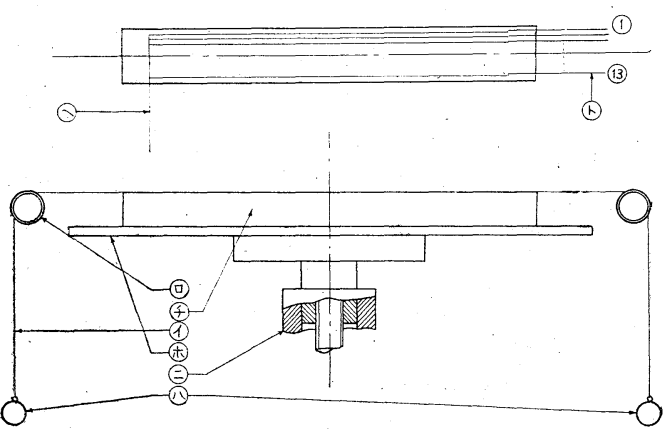

第1図 ゲージ貼付装置

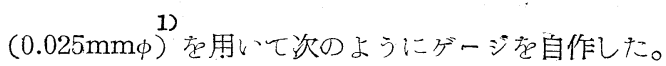

すなわち第 1 困のように上下微動調整装置（二）をも つた試料載台（ホ）の上に試料（テ）苍置き，試料の表 面にら゙ージセメント BC-1 (共和無線製) る一様に塗布 し、こ和が乾いた後に（ロ）のねぢ2個の谷（ピッチ $2 \mathrm{~mm}$ ) 学利用して両端に20g 宛の分銅（ハ）を結んだア ドバンス線（イ）热懸垂する。アドバンス線はねぢ山を 利用したか $52 \mathrm{~mm}$ 間隔に平行!二何本もはれ，本実験で は図にあるように(1)から(18までの13本の平行線ら゙ージを 作つた。所定数の線の懸垂亏終れば（二）で（ホ）をあ げ,試料面と線と芜密接せしめる。次にゲージ長 $250 \mathrm{~mm}$ だけセメント BC一1 をアドバンス線上から塗布しこ れと岩石試料々を密着せしめる。更に六の後導線死半田 付けするが一方は（へ）の如く共通に，他方は（ト）の 如く別々に付ける。(へ)(ト）を BC-1で固着せしめ, 充分乾燥し終れば，余分のアドバンス線を切断除去する。 このように岩石に直接アドバンス線を貼付する方法を採 用したのである。

\section{c) 測定器具}

ストレンメーターは新興通信製の PS-7L 型で，これ に切換箱 PS-7型 (10点切換) を用い，アクティブなら びにダミーゲージをもつて回路を組む。

かくして岩不はりに荷重を加えてこれね曲げ，その時 のアクティブゲージにあらわれたヒズミを読むのである が，(1)から(13)まで(切換箱の都合でそのうち10個を使用) の読みが一わたり済むと，はりに加わる荷重を増して再 びまだら゙ージの読みをとるのである。广お測定中の温度 の影響を抑えるために, アクティブならびにダミーの両 ゲージを貼付した岩石試料は恒温槽の中に大れ， $24^{\circ} \mathrm{C} に$ 保つて曲げ試験を行つた。

\section{d) 曲げ試験裝置}

これは既報の通りであるが，岩石はりの撓みが出来る だけ円弧に近くなるように，はりに加える荷重は集中荷 重 2 個がスパンに対称（スパン両端から $10 \mathrm{~cm}$ 宛のとこ ろ）にかけることにした。表中にある $P_{1} \sim P_{6}$ の值は集 中荷重 2 個の和で，そのおのおのはその半分である。 


\section{4. 測定結果ならびに考察}

第 2 表抢よび第 3 表は浅貝砂岩ならびに白坂頁 岩試料にお污る中性線実験結果灾示したもので， これを図示子ると，第2図抢よび第 3 図になる。 この両図で明らかなように王縮側（ゲージ番号 No. 1〜No.6), 引張側(ゲージ番号 No.8〜No.13) 共に荷重を加えるととズミね生じ，一般に荷重と 共にしズミも増大しているが，試料中央部におい、 てはとズミの増減がある。

これらの両図において，各荷重毎のヒズミが零 なる点をたどると, 最初の荷重から最後の荷重ま

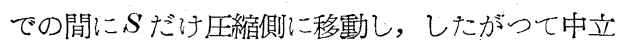
軸が荷重と共とそこまで移動したのがわかる。 元来中立軸は最初は試料中心の No.7なるゲー ジのところにあるへきで, 最初の荷重 $\left(P_{1}\right)$ によ つてもすでにいくらか圧縮側に移動してしかる心 きであるが，両試料共に最初の荷重の時にヒズミ が零なる点はNo.7とNo.8の中間にあつだここれ はゲージ貼付の技術にもよろうが，地下から取出 された岩石が整形，養生などの間にいくらかとズミが生 ずることや，岩石構成粒子が均一性を保持し難、等の理 由があげられよう。

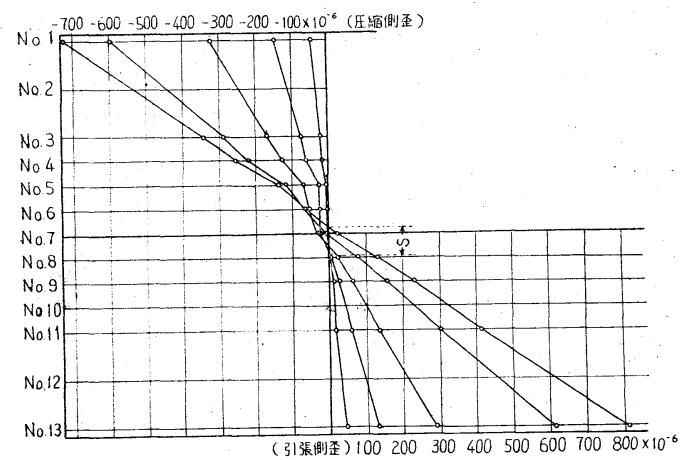

第 2 図浅具砂岩中立軸移動

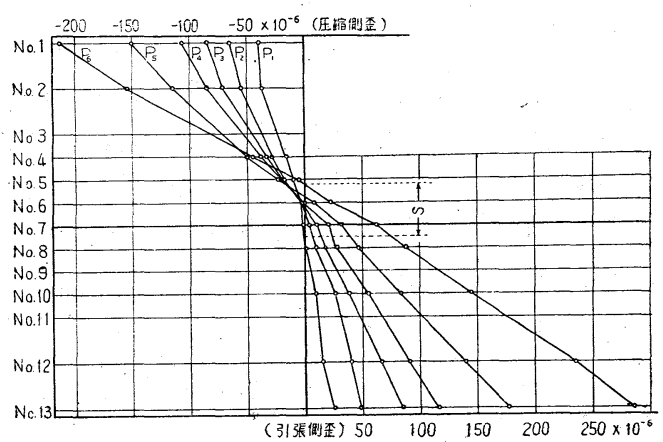

第3図白坂頁岩中立軸移動

1) Bach-Baumann : Elastizität und Festigkeit( 9 阪)S.278

\section{第 2 表}

浅貝砂岩: 長さ $30.03 \mathrm{~cm}$, 高さ $4.08 \mathrm{~cm}$, 巾 $2.55 \mathrm{~cm}$, スパン $23 \mathrm{~cm}$, ゲージ長 $250 \mathrm{~mm}$, ダミー抵抗 $241 \Omega$

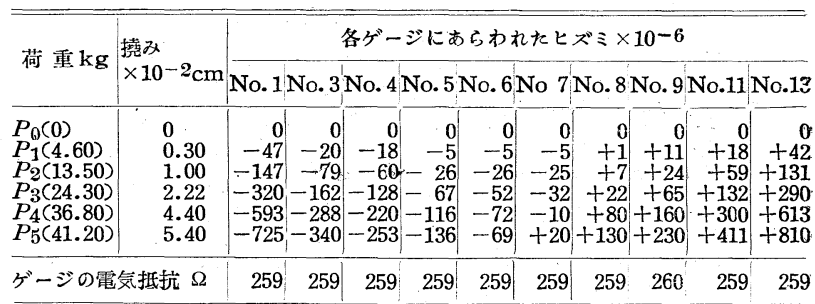

\section{第 3 表}

白坂頁岩: 長さ $30.30 \mathrm{~cm}$, 高さ $4.17 \mathrm{~cm}$, 巾 $2.69 \mathrm{~cm}$, スパン $28 \mathrm{~cm}$, ゲージ長 $252 \mathrm{~mm}$, ダミー抵抗 $285 \Omega$

\begin{tabular}{|c|c|c|}
\hline \multirow{2}{*}{$\mathrm{g}$} & \multirow{2}{*}{$\begin{array}{l}\text { 撓み } \\
10^{-2} \mathrm{~cm}\end{array}$} & 各ゲージにあらわれたヒズミ × \\
\hline & & No. 1 No. 2 No. 4 No. 5 No. 6 No. 7 No. 8 No. 10 No. 12 N \\
\hline & & 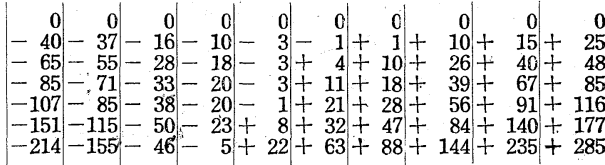 \\
\hline & & 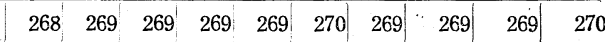 \\
\hline
\end{tabular}

いま浅貝砂岩，白坂頁岩試料について図に示した $S$ を 測ると，とれぞれ $2.4 \mathrm{~mm}$ および $4.6 \mathrm{~mm}$ に相当し，こ れを表に記した試料の高さ $40.8 \mathrm{~mm}$ 抢よび $41.7 \mathrm{~mm} に$ 比較すると，浅貝砂岩では試料の高さの $6 \%$ ，白坂頁岩 ではその11\%だけ，実験中の最初の荷重から最後の荷重 までに移動したことになる。Bachによれば，砂岩にお いては破壞間際の高い応才でも中立軸の移動は $10 \%$ を超 えないとされている。筆者の実験でも最後の荷重はほと んど破壤間際のものである。

な报既述の仮定（2）によ和ば，ヒズミは中立軸から の距離に比例して直線的に変化することになるが，本実 験におおて各荷重毎の繊維セズミえ結んだ線ははほぼ直線 とみなされ得る結果定得た。

さらに表に記したように，ヒズミの測定中同時に文ブ ルミラー法によつて試料の中央における撓みを測定し た。すなわち最後の荷重においては浅貝砂岩の撓みは $5.40 \times 10^{-2} \mathrm{~cm}$, 白坂頁岩の撓みは $2.02 \times 10^{-2} \mathrm{~cm}$ であ 当。二れ存次式

$$
\varepsilon=\frac{4 h}{l^{2}} \cdot \delta
$$

ただし $\delta:$ 試料中央の撓み

$l:$ 試料のスパン

にしたがつてとズミを計算し，かつそれからNo.13のゲ ージを貼つた引張側の繊維におけるとズミる算出する と, 浅貝砂岩では $882 \times 10^{-6}$, 白坂頁岩では $330 \times 10^{-6}$ のヒズミ值になる。これを実際に測定したせズミの值の $810 \times 10^{-6}$ 抢よび $285 \times 10^{-6}$ と比較すると，害際の方が やや小さい值になつている。 
これは岩石の撓みが完全な円弧に撓むものと考えたこ と，撓んでも岩石側面が常に平面を保つとしたこと，が ージを岩石に直接貼付したためにグージセメントをやや 多量に用いたのでこのセメント層のヒズミが影響を与 えた；等の理由放数えることが出来る。岩石試料に紙に 貼つだ゙ージぷ貼付しなからた訳は，紙を用いると，岩 石粒子間で滑つてはがれるので直接法な用いたのであ る。

なお第 4 図注本契験に用いたアドバンス線のゲージフ アクターをしらべるために自作ゲージの特性を示した曲 線である。すなわち検定用鋼製はり（厚さ $4.97 \mathrm{~mm}$ ）の

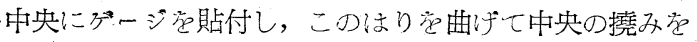

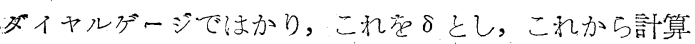
で求めたヒズミ $\varepsilon$ 注図中の点線である。一方計器炽ら゙ー ジフアクター 2.00 に調整しておいて, 操みと共に測つ たセズミの読みが静線である。この両線は四のように殆 ど一致し，かつ曲線の中央部に抢いてはほとんど $2.00 そ$ のままであつたので，本実験ではゲージフアクターを .2.00として行つたのである。

さてひるがえつて岩石試料に执いて曲げ強さが引張強 さに此心゙大なる值に算出されるのは，主として次の二 つの理由による。

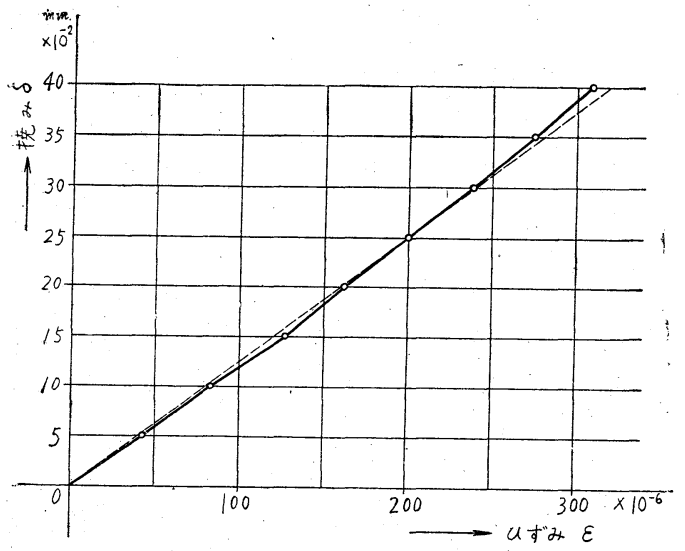

第4図アドバンス線ゲージの特性

（1）本箺験におけりるように中立軸が圧縮側に移動す るから，強さの弱、方の引張側はたと元圧縮側より大な るせズミ存生じても，曲げモーメントをうけもつのに压 縮側より大なる面積でうけもっためである。

（2）応力の増加に関しては， $\varepsilon=\alpha \sigma^{m}$ でかっ $m>1 な$ る関倸から，その曲線は中立軸から遠い外皮瀻維に近い 程増加が緩やかであるので，中立軸に近い程㐫力に対し て抵抗する役割学よりよく果すからである。

このため $\varepsilon=\alpha \sigma$ を仮定して算出した曲け強さは引張強 ささより大になって算出されるのである。
5. 結 … 論

（1）本研究は岩石の曲げ強さが引張強さより大にな つて算出される理由の一つとして曲げにお㧍る中立軸の 移動について研究したものである。

（2）中立軸の移動はははりの縱繊維に平行に貼られた アドバンス線グージによつて電気的に測定した。

（3）その結果本実験の荷重範囲内では白坂頁岩にお いてははりの高さの $11 \%$ ，浅貝砂岩に㧊いては $6 \%$ も圧 縮側に移動することを認めた。

（4）また，はりの縱繊維の各々のとズミと荷重との 関係はほとんど直線とみなされ得る。

（5）以上の研究によつて曲け強さが弓張強さより大 に算出されることの一つの論抛を証明した。

\section{謝 辞}

本研究の一部は文部省科学研究費によつて遂行され た。

本研究走行うにあたり，東大名誉教授青山博士なら びに東大教授水田博士は終始御懇切なる御指導应賜わつ た。

東北大学助手小林良二, 西方兵衛両学士心研究に協力 され, 丹野明, 石田昭夫, 八重樫成一郎三学士は卒羓研 究として実験に助力された。

また常磐炭硠磐城矿業所は実験試料の採取に多大の便 宜を与えられた。

ここに謹んで感謝の意を表する。

\section{近刊予告}

技術對畫第11輯（鉙床探查 2 )

\section{鉱 床亡地 質構 造（第2 集）}

\section{A 5 判 120面 别紙図面 13葉 定価未定}

第 1 集に引蹚き，鉒石，中竞，赤，イトムカ，稻倉石，高玉，紀州 生野, 植峰, 南九州, 烟, 下川, 奈良杤原, 新宮, 佬々連, 別子, 大 久喜, 愛旅県西部以上15鉱山，3地区の鉱床き地質構浩について, 図面 を豊富に挿入して詳述している。

技術叢書第12輯（鉣床探查 3 ）

\section{鉱山の物 理 探 鉱}

\section{A 4 判全部図面，定価未定}

鉱山における物理探鉱は近来急速度で淮步している。この書は余市, 上北，花岡，明又，松尾，野田玉川，鉒石，細会，小串，越路，久 根，妙法，河山以上14鉱山で実際に行われれ結果を図面で表わしれる のを集錄したもので，わが国においては初めての試みであり,状態の異

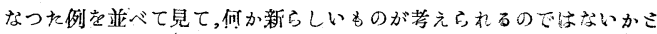
思わ机る。 